\title{
Virus and virus-like diseases of grapevine in Hungary
}

\author{
Lázár, J. ${ }^{1}$ \& Bisztray, Gy. D.² \\ ${ }^{1}$ Corvinus University of Budapest, Institute of Viticulture and Oenology, Research Station Kecskemét \\ 6001 Kecskemét, P.O.Box 25, Hungary \\ ${ }^{2}$ Corvinus University of Budapest, Institute of Viticulture and Oenology, Department of Viticulture \\ 1118 Budapest, Villányi út 29-43, Hungary
}

\begin{abstract}
Summary: Viruses and viroids are submicroscopic infectious particles which can cause disease symptoms on grapevine. These parasites are depending completely on the energy metabolism of the plant cell. To enter the host cell plant viruses depend on injuries or on transmission via invertebrates (insects, nematodes, etc.). Viruses are classified by many characters including particle morphology, host range and information content of the genome. At present about 70 viruses including 7 viroids infecting grapevine are known. In single or mixed infections they are potentially detrimental to the quality and quantity of grape production in any growing area of the world. Some viruses can cause severe economic damage in vineyards. In Hungary many important viruses and viroids have been detected in grape. This review summarises characteristics of viruses and the results of detection and characterization of virus and virus like diseases of grapevine in Hungary. The identification of the causal agent, its transmission, geographical distribution and the development of the diagnostic methods are also discussed.
\end{abstract}

Keywords: viruses, viroids, Vitis vinifera, grapevine diseases, virus detection

\section{The agents of virus-diseases}

A virus is an infectious agent, often highly host-specific, consisting of genetic material surrounded by a protein coat.

The word is from the Latin virus referring to poison and other toxious substances, first used in English in 1392. Virulent, from Latin virulentus (poisonous), dates to 1400 . A meaning of "agent that causes infectious disease" is first recorded in 1728, before the discovery of viruses by Ivanovsky in 1892. The adjective viral dates to 1948. The term virion is also used to refer to a single infective viral particle.

Viruses infect virtually every life form, including humans, animals, plants, even fungi, bacteria and fytoplasmas. So small that they cannot be seen by a light microscope, viruses range in size from about 30 nanometers to about 450 nanometers and are between 100 to 20 times smaller than bacteria. Known viruses have been assigned to about 1600 species in more than 100 different families. Hundreds of other viruses remain unclassified due to lack of information.

All standard viruses share a general structure of genetic material, or viral genom, and a protein coat, called a capsid. The viral genome is made of either dezoxyribose nucleic acid (DNA), the genetic material found in plants and animals, or ribonucleic acid (RNA), a compound plant and animal cells use in protein synthesis (Table 1). Viruses are not strictly free-living, as they cannot reproduce on their own. Instead, they use host cell machinery to make both the viral genome and capsid of the newly formed viruses, or virions.

Virus particles (known as virions) consist of two or three parts: the genetic material made from either DNA or RNA, long molecules that carry genetic information; a protein coat that protects these genes; and in some cases an envelope of lipids that surrounds the protein coat when they are outside a cell. The shapes of viruses range from simple helical and icosahedral forms to more complex structures.

The broad category of viruses also includes unusual infective agents that are missing one or more components of standard viruses. These unconventional viruses include viroids, which exist as circular RNA molecules that are not packaged.

The origins of viruses in the evolutionary history of life are unclear: some may have evolved from plasmids - pieces of DNA that can move between cells - while others may have evolved from bacteria. In evolution, viruses are an important means of horizontal gene transfer, which increases genetic diversity.

\section{Plant viruses and virus-diseases}

Like all other viruses, plant viruses are obligate intracellular parasites that do not have the molecular machinery to replicate without a host. Plant viruses are pathogenic to higher plants.

Although plant viruses are not nearly as well understood as the animal counterparts, one plant virus has become iconic. The first virus to be discovered was Tobacco mosaic virus (TMV). This and other viruses cause an estimated nearly EUR 40 billion loss in crop yields worldwide each year. Plant viruses are grouped into 73 genera and 49 families. To transmit from one plant to another and from one plant cell to another, plant viruses must use strategies that are usually different from animal viruses. Plants do not move, and so plant-to-plant transmission usually involves vectors 
Table 1. Genomic diversity among viruses

\begin{tabular}{|c|c|c|}
\hline \multicolumn{2}{|l|}{ Property } & Parameters \\
\hline \multirow{3}{*}{ Nucleic acid } & - & DNA \\
\hline & - & RNA \\
\hline & $\bullet$ & $\begin{array}{l}\text { Both DNA and RNA (at different stages } \\
\text { in the life cycle) }\end{array}$ \\
\hline \multirow{3}{*}{ Shape } & - & Linear \\
\hline & - & Circular \\
\hline & - & Segmented \\
\hline \multirow{3}{*}{ Strandedness } & - & Single-stranded \\
\hline & $\bullet$ & Double-stranded \\
\hline & $\bullet$ & $\begin{array}{l}\text { Double-stranded with regions of } \\
\text { single-strandedness }\end{array}$ \\
\hline \multirow{3}{*}{ Sense } & - & Positive sense $(+)$ \\
\hline & $\bullet$ & Negative sense (-) \\
\hline & - & Ambisense (+/-) \\
\hline
\end{tabular}

(such as insects). Plant cells are surrounded by solid cell walls, therefore transport through plasmodesmata is the preferred path for virions to move between plant cells. Plants probably have specialized mechanisms for transporting mRNAs through plasmodesmata, and these mechanisms are thought to be used by RNA viruses to spread from one cell to another.

The discovery of plant viruses causing disease is often accredited to Beijerinck who determined, in 1898, that plant sap obtained from tobacco leaves with the "mosaic disease" remained infectious when passed through a porcelain filter. This was in contrast to bacteria microorganisms, which were retained by the filter. Beijerinck referred to the infectious filtrate as a "contagium vivum fluidum", thus the coinage of the modern term "virus". After the initial discovery of the 'viral concept' there was need to classify any other known viral diseases based on the mode of transmission even though microscopic observation proved fruitless. In 1939 Holmes published a classification list of 129 plant viruses. This was expanded and in 1999 there were 977 officially recognized, and some provisional, plant virus species.

The purification (crystallization) of TMV was first performed by Stanley, who published his findings in 1935, although he did not determine that the RNA was the infectious material. However, he received the Nobel Prize in Chemistry in 1946. In the 1950s a discovery by two labs simultaneously proved that the purified RNA of the TMV was infectious which reinforced the argument. The RNA carries genetic information to code for the production of new infectious particles.

More recently virus research has been focused on understanding the genetics and molecular biology of plant virus genomes, with a particular interest in determining how the virus can replicate, move and infect plants. Understanding the virus genetics and protein functions has been used to explore the potential for commercial use by biotechnology companies. In particular, viral-derived sequences have been used to provide an understanding of novel forms of resistance. The recent boom in technology allowing humans to manipulate plant viruses may provide new strategies for production of value-added proteins in plants.

Over $50 \%$ of known plant viruses are rod-shaped (flexuous or rigid). The length of the particle is normally dependent on the genome but it is usually between $300-500 \mathrm{~nm}$ with a diameter of 15-20 nm. Protein subunits can be placed around the circumference of a circle to form a disc. In the presence of the viral genome, the discs are stacked, then a tube is created with room for the nucleic acid genome in the middle.

The second most common structure amongst plant viruses are isometric particles. They are $40-50 \mathrm{~nm}$ in diameter. In cases when there is only a single coat protein, the basic structure consists of $60 \mathrm{~T}$ subunits, where $\mathrm{T}$ is an integer. Some viruses may have 2 coat proteins are the associate to form an icosahedral shaped particle.

There are three genera of Geminiviridae that possess geminate particles which are like two isometric particles stuck together.

A very small number of plant viruses have, in addition to their coat proteins, a lipid envelope. This is derived from the plant cell membrane as the virus particle buds off from the cell.

Viral particles won't survive outside its host tissue. That means they need a vector to move from one plant to another. Vectors include insects (as nematodes, leafhoppers, aphids, mealybugs or soft scale insect vectors) and pruning and propagating tools that move sap from one plant to another. Viral particles also can be moved through other plant parts such as seeds, pollen or the plant itself.

Like any living system, plants are susceptible to viral diseases. Testing for viruses in plants is costly, so diagnosis often is based on symptoms. Some common symptoms include mottling or mosaics expressed as a variegated pattern of yellow and green on the leaf, fruit or flower; curled or distorted leaf tissue that feels thick and rigid, even though the plant appears wilted; and stunting and distortion, which may appear as abnormally shortened or deformed leaves, stems or fruit. Ring spots appear as wavy rings or lines of yellow, white or red throughout leaf tissue; and cankers cause blackened areas or black streaks to appear on stems.

Unfortunately, there is no chemical control for viral disease. The only way to reliably control viral diseases is to remove symptomatic plants and control the insect vector, if appropriate. When working with multiple plants, it's always best to clean pruning and propagating tools to avoid "passing" the virus from one plant to another.

\section{Viruses and virus diseases of grapevine in Hungary}

Among grapevine diseases those caused by viruses deserve full attention due to their detrimental effects and modes of spread. Their causal agents are characterized by a high cell parasitism and some may naturally be distributed by 
soil-borne or air-borne vectors, although in most cases they are transmitted by propagative material.

In Hungary the detection of virus and virus-like diseases of grapevine began in 1960's in the Research Institute for Viticulture and Enology by János Lehoczky and his colleagues.

At present, seventeen virus and virus-like diseases of Vitis sp. are known to occur in Hungary (Lehoczky et al., 1992; Lázár et al., 2000) (Table 2). Some of these viruses, for example fanleaf and leafroll cause significant yield loss and/or lower fruit quality. Other virus diseases, for example, Rugose wood complex can provoke untimely death of grapevine stocks. A few viruses are latent. Little is known about their effects on grapevine, however occurrence of these diseases is quite frequent, so they may have high economic importance.

Fanleaf virus and the related strains (Yellow mosaic and Veinbanding) are most widespread and present in almost all vine-growing regions of Hungary. Other nepoviruses: Arabis mosaic, Chrome mosaic, Tomato black ring are not so frequent. Symptoms of Enation, Yellow mottle, Line pattern were observed only in one or two cases in the vine-growing regions. Rugose wood complex (RW), Leafroll and Vein mosaic are widely distributed in almost all the main grapevine-growing regions of Hungary, affecting the major table and wine varieties (Lázár, 2003). Fleck and Vein necrosis can be often found on the indexed varieties and rootstocks, with incidence varying from 50 to $80 \%$.

\section{Fanleaf and strains}

Fanleaf is the oldest known and one of the most important and widespread virus diseases of the grapevine. Origin in the Mediterranean Basin, now the disease is known to occur world-wide (Hewitt, 1976).

Main symptoms: malformations of leaves, asymmetrical, may show open petiolar sinuses and acute denticulations, give the leaf the appearance of an open fan. Shoots are also malformed, showing abnormal branching, double nodes, short internodes, and zigzag growth (Figure 1). Chromogenic strains cause striking yellowing of the foliage in the springsummer period (Figure 2). Bunches are reduced in number and size, ripen irregularly and have shot berries and poor berry setting.

Agent: Grapevine fanleaf nepovirus (GFLV) (Hewitt, 1954). Isometric particles of $30 \mathrm{~nm}$ in diameter, with a bipartite genome made up of two functional single-stranded RNA species (7342 nt, RNA-1 and 3774 nt, RNA-2) (Quacquarelly et al., 1976). Some strains of GFLV have an additional sattellite RNA (1114 nt) (Fuchs et al., 1991).

Geographical distribution: see Table 2. Reported from Hungary first time in 1964 (Sárospataki, 1964, 1965; Lehoczky, 1965). GFLV is the fifth most common virus on European grapes in Hungary (Lázár \& Terjék, 2009; Cseh et al., 2011).

Transmission: Transmitted by grafting and sap inoculation. Vector, see Table 2. There are conflicting reports

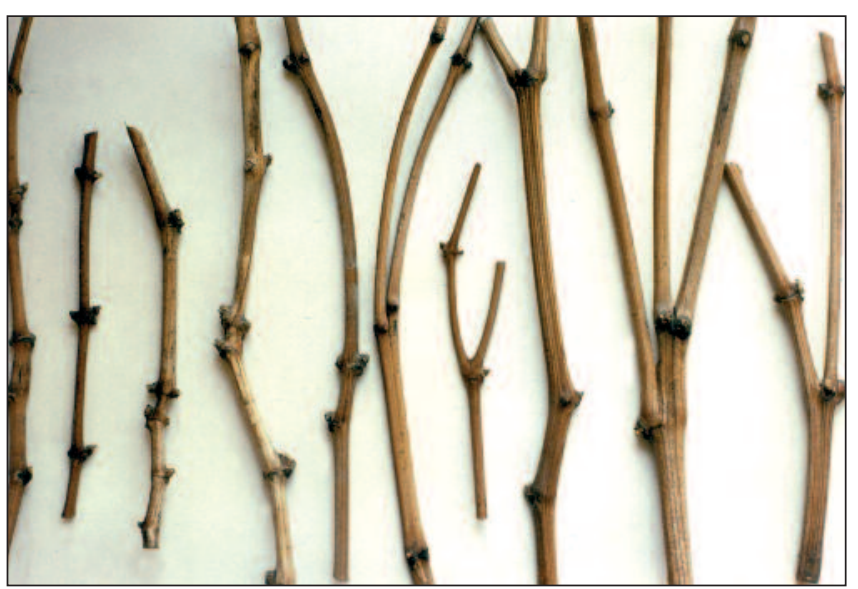

Figure 1. Fanleaf (GFLV) - atipical chronic symptoms in Vitis vinifera canes - malformation, short internodes, double nodes, etc.

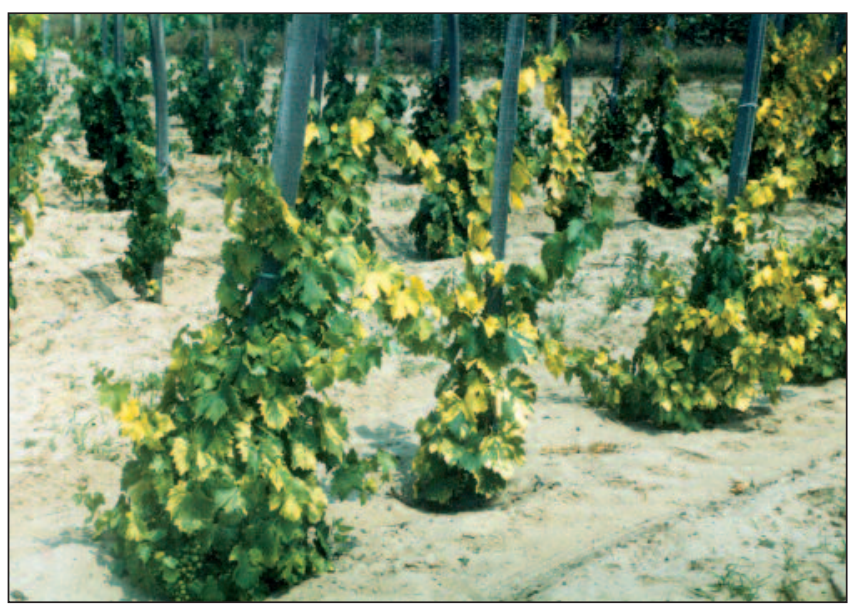

Figure 2. Fanleaf - chromogenic virus strain (GFLV-YM): bright yellow discolourations of the foliage

on seed transmission in grapevines (Hévin et al., 1973; Lázár et al., 1990). Natural GFLV infections have been detected in weeds in Hungary and Iran (Horváth et al., 1994; Izadpanah et al., 2003).

\section{Other nepoviruses}

Besides GFLV several other nepoviruses can infect grape varieties in Hungary. These are, Arabis mosaic (ArMV), grapevine chrome mosaic (GCMV), tomato black ring (TBRV) and grapevine Bulgarian latent (GBLV) viruses. All of them have polyhedral particles about $30 \mathrm{~nm}$ in diameter and a positive sense, bipartite RNA genomes. Symptoms similar to those induced by fanleaf virus: cane and leaf deformation, chlorotic mottling, reduced vigour, heavy crop losses and bright yellow discolourations (chromogenic strains) (Martelli \& Boudon-Padieu, 2006). These are transmitted by grafting and sap inoculation too. Their geographical distribution and vectors can be seen in Table 2 .

ArMV, member of the genus Nepovirus, is serologically related to GFLV. In several Vitis vinifera varieties, symptoms are similar of the fanleaf (chromogenic strains) type (Figure 3). Shock symptoms (chlorotic rings and lines) are in Vitis 


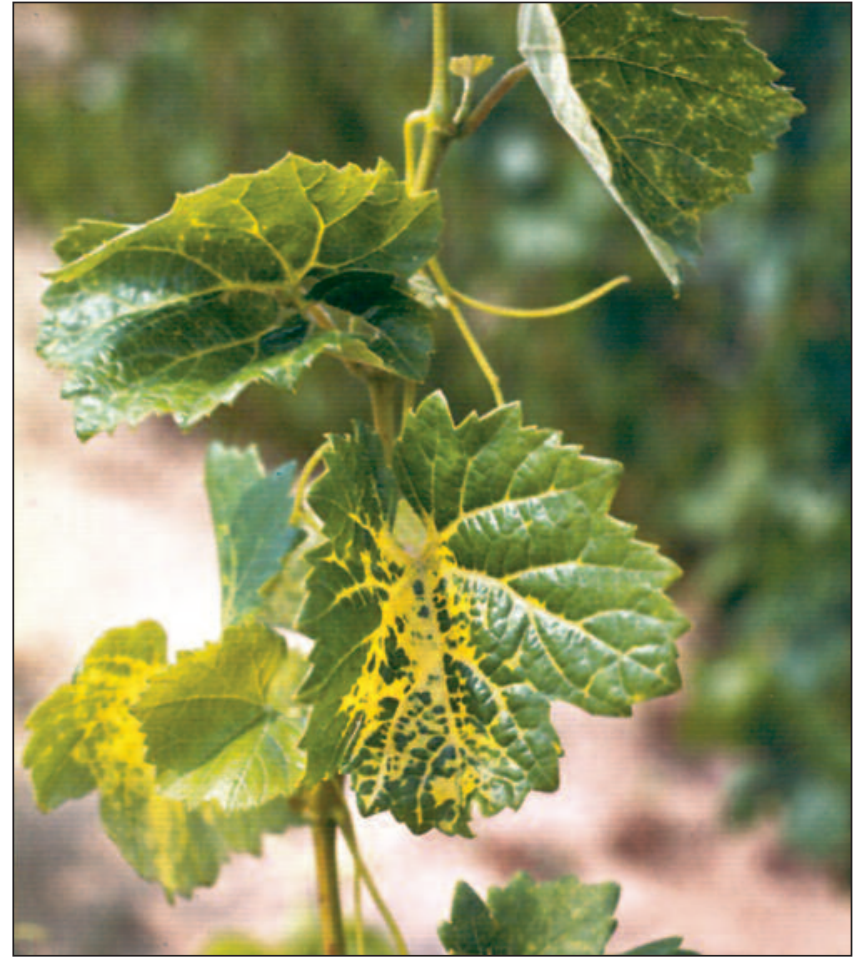

Figure 3. Arabis mosaic (ArMV) - tipical leaf-symptoms in Vitis vinifera $\mathrm{cv}$. Hárslevelü

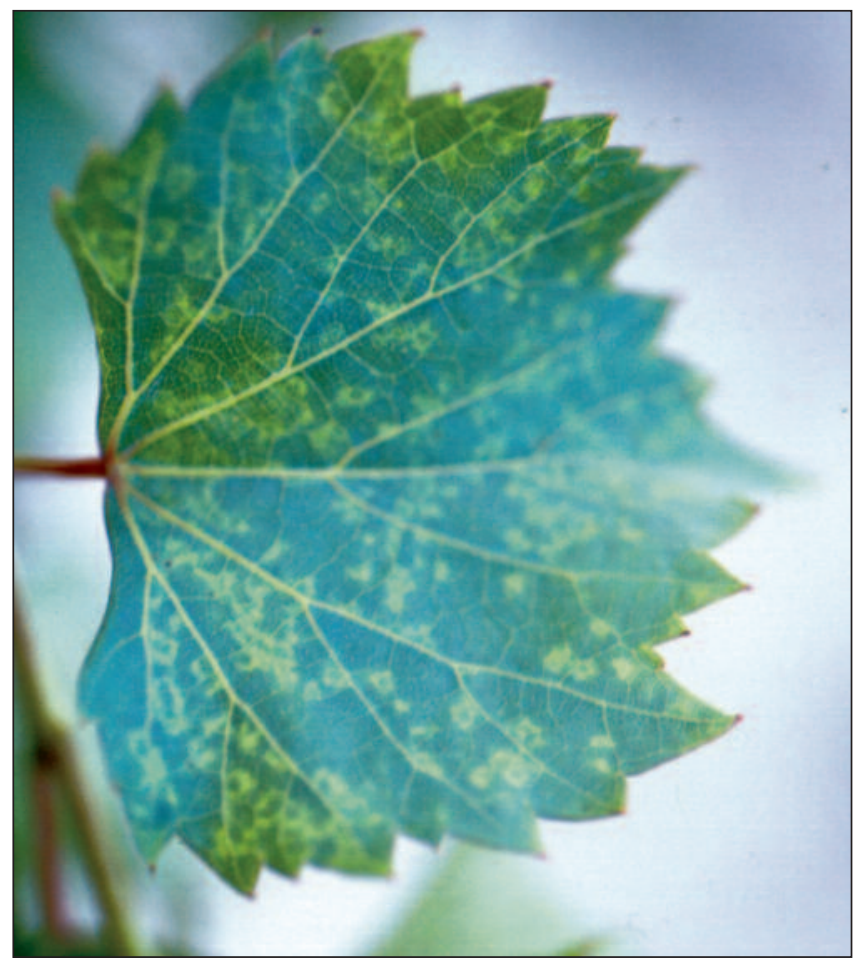

Figure 4. Arabis mosaic (ArMV) - shock symptoms (chlorotic rings and lines) in Vitis rupestris

rupestris St. George indicator (Figure 4). It was first identified on grapevine in Croatia (Panjan \& Saric, 1963). It can infect many woody and herbaceous plants (weeds) (Jenser et al., 1979). Martelli and Lehoczky (1968) identified it on grapevine in several wine-district of Hungary. ArMV is not seed-transmitted in grapevines (Lázár et al., 1990).

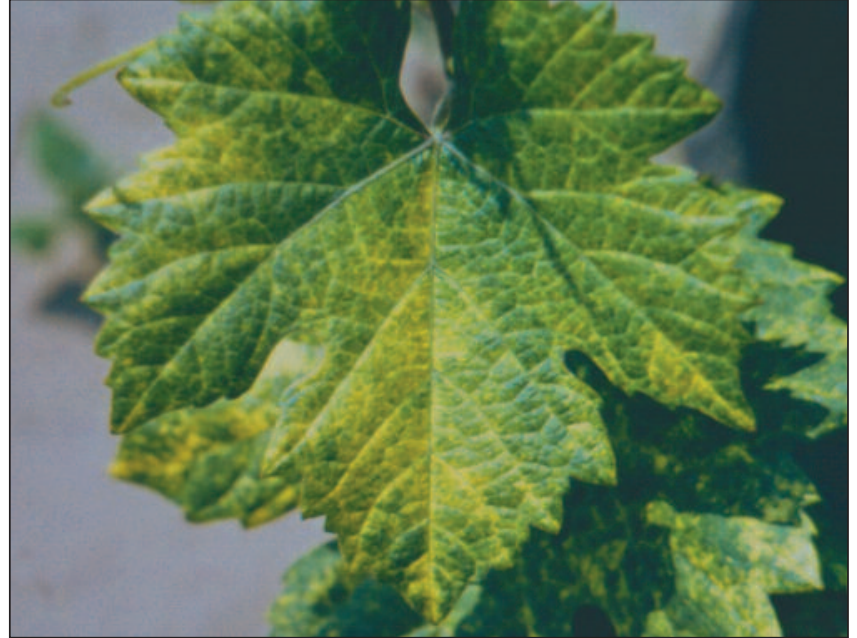

Figure 5. Chrome mosaic (GCMV) - symptoms in Vitis vinifera cv. Szerémi zöld: leaves partially or entirely bright yellows or whitish

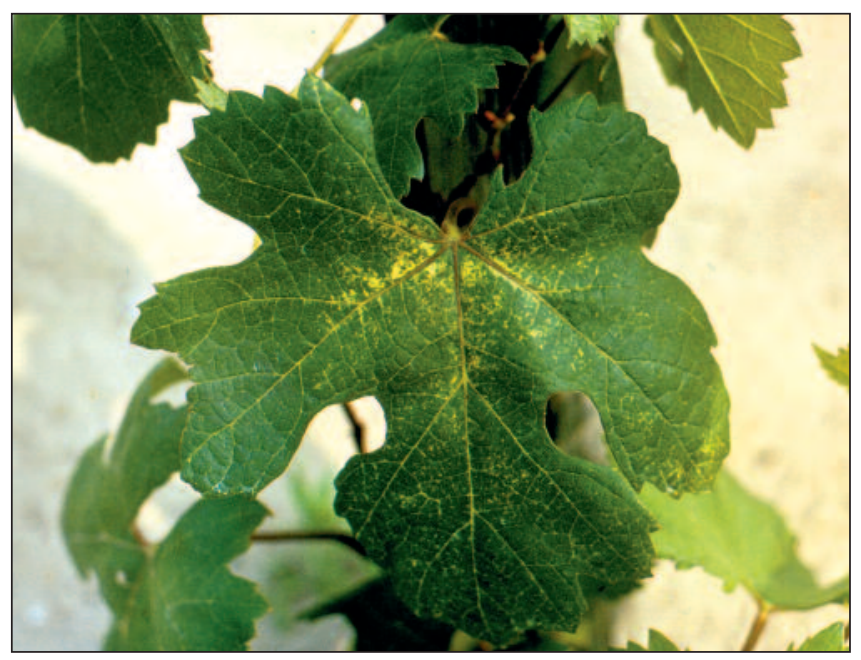

Figure 6. Tomato black ring (TBRV) - chlorotic spots, rings and lines on the leaves

GCMV was reported by Martelli et al., (1965) in Hungary on cvs. Red Veltliner, Szerémi zöld (Figure 5) and Budai green displaying „yellow-like” symptoms. These are similar than yellow mosaic strain (Kobza \& Lázár, 1994). The tipical disease symptoms developed on Pinot noir and Jubileum 75 in the second year after grafting (Lehoczky, 1985). The virus belongs in the same subgroup of TBRV (subgroup B) to which is distantly related serologically (Lehoczky et al., 1979). GCMV is seed-transmitted in grapevine (Lázár et al., 1990).

$T B R V$ was recorded in 1963 from Germany in the Moselle area by Stellmach and Bercks. It provokes mottling, chlorotic ringspot (Figure 6), line pattern and inhibits growth. Losses are not know precisely, but they can be high. The first report in Hungary was by Lehoczky and Burgyán (1986).

$G B L V$ spread in Bulgaria on symptomless Rcatzitelli grape variety. It has been identified in Hungary (Pocsai, 1981) and Serbia while the CM 112 strain was described from Portugal (Ferreira, 1972). The economic importance of the virus is minor. 


\section{Grapevine leafroll associated viruses}

Leafroll is a complex and severe syndrome, widely distributed in all the viticultural areas of the world. Evidence from a herbarium that leafroll occurrence in Sicily in the second half of the 19th century (Martelli \& Piro, 1975). There are reports of early reddening of grapevine leaves regarded as physiological disorders and referred to as „Rossore” or „Rugeau” in the Italian and French literature, respectively (Sannino, 1906; Ravaz \& Verge, 1924). Leafroll is probably the most widespread virus disease of grapevine and is no less important than fanleaf in economic importance.

Main symptoms: downward rolling and discoloration of the leaves, which turn reddish-purple or yellowish in red- and white-fruited cultivars, respectively (Figure 7-8). Bunches may be small and with discoloured and tasteless berries. The leave symptoms progress towards the top of the canes as the season advances. In most cases, infection of rootstocks is symptomless, except for a variable decrease in vigour. In that case, the risk of disseminating the disease is great if untested rootstocks are used.

Agents: in this time nine different viruses with filamentous particles have been found in leafroll-infected vines (GLRaV 1-9).

Grapevine leafroll-associated virus 1 (GLRaV-1)

(Gugerli et al., 1984);

Grapevine leafroll-associated virus 2 (GLRaV-2)

(Gugerli et al., 1984);

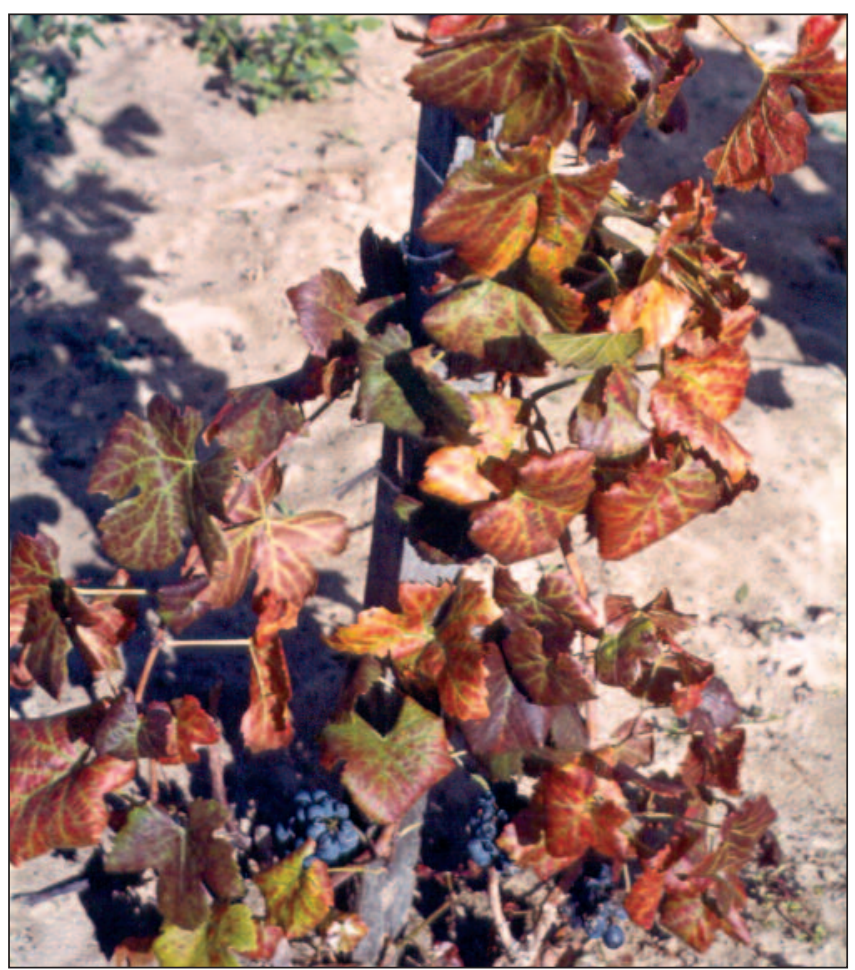

Figure 7. Leafroll (GLRaVs) - typical symptoms on leaves of red varieties: rolling and reddening
Grapevine leafroll-associated virus 3 (GLRaV-3) (Rosciglione \& Gugerli, 1986);

Grapevine leafroll-associated virus 4 (GLRaV-4) (Hu et al., 1990);

Grapevine leafroll-associated virus 5 (GLRaV-5)

(Walter \& Zimmermann, 1990);

Grapevine leafroll-associated virus 6 (GLRaV-6) (Boscia et al., 1995);

Grapevine leafroll-associated virus 7 (GLRaV-7) (Choueiri et al., 1996);

Grapevine leafroll-associated virus 8 (GLRaV-8) (Monis, 2000);

Grapevine leafroll-associated virus 9 (GLRaV-9) (Alkowni et al., 2002);

All GLRaV's belong in the family Closteroviridae, GLRaV-2 in the genus Closterovirus, GLRaV-1, GLRaV-3, GLRaV-6, GLRaV-8 and GLRaV-9 in the newly established genus Ampelovirus (Martelli et al., 2002), whereas GLRaV7 is presently classified as unassigned species to the family. Particle length varies from $1400 \mathrm{~nm}$ to $2200 \mathrm{~nm}$.

To date, from these have been identified six GLRaV's (GLRaV-1, GLRaV-2, GLRaV-3, GLRaV-4 (Lázár et al., 1994) and GLRaV-6, GLRaV-7 (Lázár et al., unpublished data) in Hungary.

Geographical distribution: see Table 2. Reported from Hungary first time in 1969 (Lehoczky et al., 1969; Lázár et al., 1994).

Transmission: transmitted by the infected propagation material. Vectors, see Table 2.

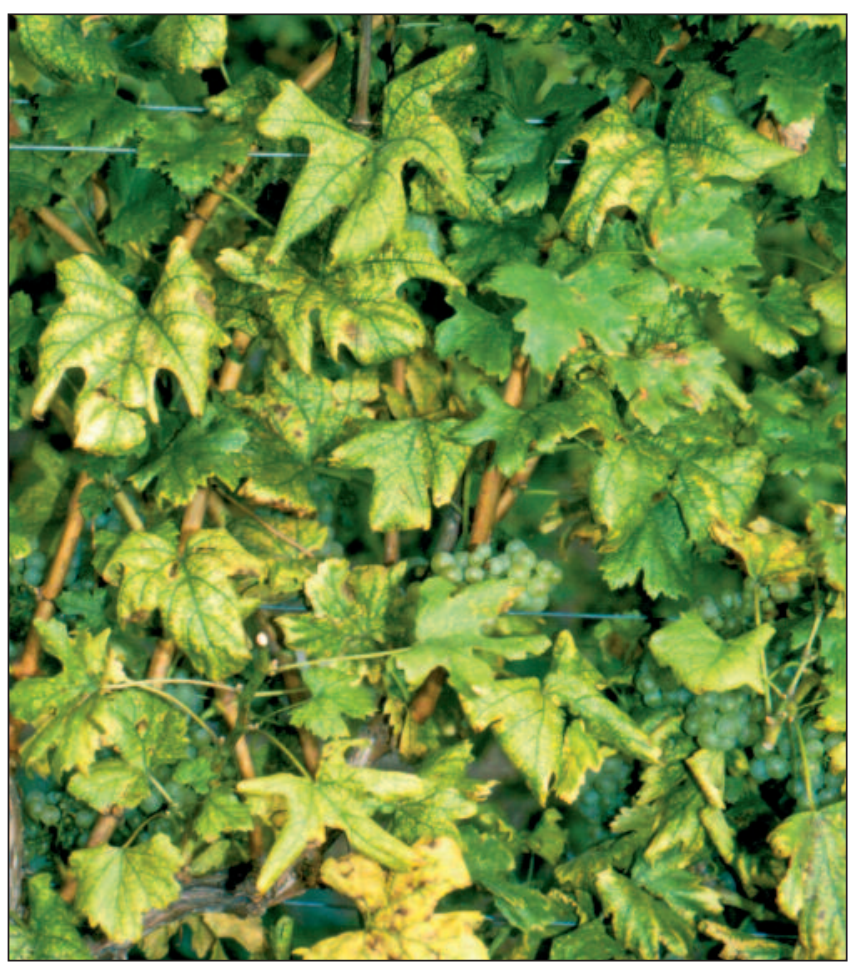

Figure 8. Leafroll (GLRaVs) - typical symptoms on leaves of white varieties: rolling and yellowing 
Table 2. Grapevine viruses, virus-like diseases of grapevines in Hungary. Some properties and characteristics.

\begin{tabular}{|c|c|c|c|c|c|c|}
\hline Disease & Virus & Acr. & $\begin{array}{l}\text { Geographic } \\
\text { distribution }\end{array}$ & $\begin{array}{c}\text { Economic } \\
\text { loss (1) }\end{array}$ & $\begin{array}{l}\text { Particle } \\
\text { type (2) }\end{array}$ & Vector to grapevine \\
\hline \multicolumn{7}{|c|}{ 1. Nepo viruses } \\
\hline Fanleaf & 1.1 grapevine fanleaf virus & GFLV & World-wide & ++++ & $\mathrm{P}$ & Xiphinema index (HU) (3) \\
\hline Yellow mosaic & $\sim$ yellow mosaic strain & GFLV-YM & World-wide & ++++ & $\mathrm{P}$ & Xiphinema index $(\mathrm{HU})$ \\
\hline Vein banding & $\sim \mathrm{GFLV}+\mathrm{GYSVd}$ & GFLV-VB & World-wide & ++++ & $P$ & Xiphinema index $(\mathrm{HU})$ \\
\hline Arabis mosaic & 1.2 Arabis mosaic virus & ArMV & Prob. world-wide & +++ & $\mathrm{P}$ & Xiphinema diversicaudatum (HU) \\
\hline Chrome mosaic & 1.4 grapevine chrome mosaic virus & GCMV & HU, CZ, SK, HR, AT & +++ & $\mathrm{P}$ & Probably nematodes \\
\hline Tomato black ring & 1.5 tomato black ring virus & TBRV & $\begin{array}{l}\text { DE, SRB, HR, HU, } \\
\text { GR, ISR, TR, CA }\end{array}$ & ++ & $\mathrm{P}$ & Longidorus attenuatus (HU) \\
\hline Bulgarian latent & $\begin{array}{l}1.3 \text { grapevine Bulgarian } \\
\text { latent virus }\end{array}$ & GBLV & $\begin{array}{l}\text { BG, PT, USA, SRB, } \\
\mathrm{HR}, \mathrm{HU}\end{array}$ & + & $P$ & Probably nematodes \\
\hline \multicolumn{7}{|c|}{ 2. Grapevine leafroll complex } \\
\hline Leafroll & $\begin{array}{l}\text { grapevine leafroll associated viruses } \\
1-3\end{array}$ & GLRaV's & World-wide & ++++ & $\mathrm{F}$ & $\begin{array}{l}\text { GLRaV-1: Heliococcus bohemicus } \\
\text { (HU), Phenacoccus aceris (HU), } \\
\text { Pulvinaria vitis (HU), cont. see } \\
\text { below (4) }\end{array}$ \\
\hline \multicolumn{7}{|c|}{ 3. Rugose wood complex } \\
\hline $\begin{array}{l}\text { Rupestris stem } \\
\text { pitting }\end{array}$ & $\begin{array}{l}3.1 \text { grapevine rupestris stem } \\
\text { pitting-assoc. virus }\end{array}$ & GRSPaV & Prob. world-wide & +++ & $\mathrm{F}$ & Unknown \\
\hline Kober stem grooving & 3.2 grapevine virus $\mathrm{A}$ & GVA & Prob. world-wide & ++++ & $\mathrm{F}$ & $\begin{array}{l}\text { Pl. citri }{ }^{*}, \text { Pl. ficus }{ }^{*}, P s . \\
\text { longispinus, cont. see below(5) }\end{array}$ \\
\hline LN33 stem grooving & Unknown & LNSG & Prob. world-wide & + & $\mathrm{U}$ & Unknown \\
\hline \multicolumn{7}{|c|}{ 4. Fleck complex } \\
\hline Fleck & 4.1 grapevine fleck virus & GFkV & World-wide & +++ & $\mathrm{P}$ & Unknown \\
\hline \multicolumn{7}{|c|}{ 5. Minor virus diseases } \\
\hline $\begin{array}{l}\text { Grapevine yellow } \\
\text { mottle }\end{array}$ & 5.1 alfalfa mosaic virus & AMV & $\begin{array}{l}\text { DE, CH, CZ, SK, BG, } \\
\text { TR, HU }\end{array}$ & $?$ & B & Suspected to be aphids \\
\hline Grape. line pattern & 5.2 grap. line pattern virus & GLPV & Hungary & + & $\mathrm{P}, \mathrm{B}$ & Unknown \\
\hline \multicolumn{7}{|c|}{ 6. Virus-like diseases } \\
\hline Grape. enation disea. & Unknown & GED & Prob. world-wide & $?$ & $\mathrm{U}$ & Unknown \\
\hline Grape. vein mosaic & Unknown & GVM & Prob. world-wide & $?$ & $\mathrm{U}$ & Unknown \\
\hline Grape. vein necrosis & Unknown & GVN & Prob. world-wide & + & $\mathrm{U}$ & Unknown \\
\hline \multicolumn{7}{|c|}{ 7. Viroids } \\
\hline Yellow speckle & $\begin{array}{l}7.1 \text { grapevine yellow speckle } \\
\text { viroids } 1-2\end{array}$ & GYSVd-1,2 & World-wide & $?$ & $\mathrm{R}$ & Unknown \\
\hline Hop stunt & 7.2 hop stunt viroid & HSVd-g & World-wide & $?$ & $\mathrm{R}$ & Unknown \\
\hline
\end{tabular}

Note: (1) += low, ++ = medium, +++ = high, ++++ = very high, (2) R=Rod, F=Filamentous, P=Polyhedral, B=Bacilliform, U=Unknown (3) (HU) = occurrence in Hungary (4) Parthenolecanium corni (HU), Neopulvinaria innumerabilis, GLRaV-2: Unknown, GLRaV-3: Pl. ficus (HU)*, Pl. citri (HU)*, (* near by greenhouses), Pseuducoccus longispinus, Ps. calceolariae, Ps. maritimus, Ps. affinis, Ps. viburni, Ps. comstocki **(appearance expected, Kozár Ferenc, verbal communication), P. vitis (HU), N. innumerabilis, (5) Ps. affinis, H. bohemicus (HU), N. innumerabilis

\section{Kugose wood complex}

Rugose vood is a graft-transmissible disease-complex, consist of several diseases:

- Rupestris stem pitting (Goheen, 1988) (Figure 9),

- Kober stem grooving (Savino et al., 1987) (Figure 10),

- Corky bark (Hewitt et al., 1962) (Figure 11),

- LN33 stem grooving (Garau et al., 1989) (Figure 12), widely distributed in all the vine-growing countries on grafted varieties and to a lesser extent on American rootstocks.

Main symptoms: reduced vigour, delayed bud opening in spring, reduced yield, swelling of the trunk above the bud union, sometimes showing thick and rough bark with spongy texture. Woody cylinder of scion, rootstock, or both, marked by pits and/or grooves corresponding to peg- and ridge-like protrusions on the cambial surface of the bark (Figure 13-14). No specific symptoms on the foliage, but vines may decline and die. Certain cultivars and rootstocks are symptomless carriers (Frison \& Ikin, 1991), however some roootstock varieties used as indicator plant are sensitive showing altered development (Lázár et al., 2002, 2003).

Agents: Putative agents of individual diseases of the rugose wood complex are members of the genera Vitivirus or Foveavirus, family Flexiviridae, i.e. viruses with flexuous filamentous particles from about 730 to $800 \times 12 \mathrm{~nm}$, with distinct transverse cross banding (Martelli \& BoudonPadieu, 2006).

Grapevine rupestris stem pitting-associated virus 


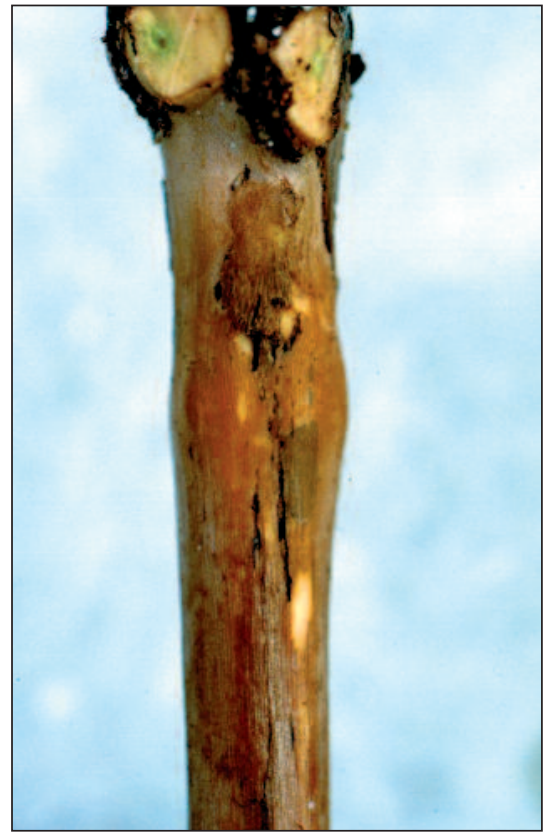

Figure 9. Rupestris stem pitting (GRSPaV) symptoms on Vitis rupestris St. George: pits below the donor tissue inoculated by chipbuddung

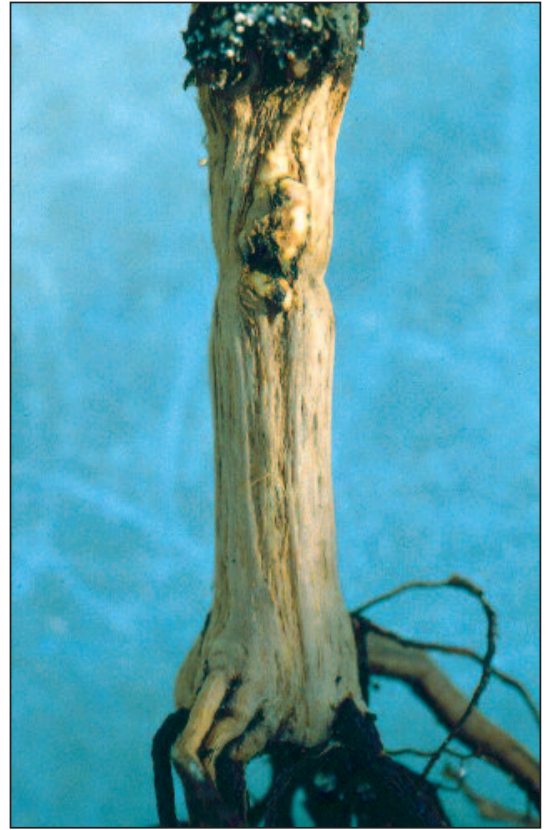

Figure 10. Kober stem grooving (GVA) symptoms on Kober 5BB: grooves around the woody cylinder of the indicator

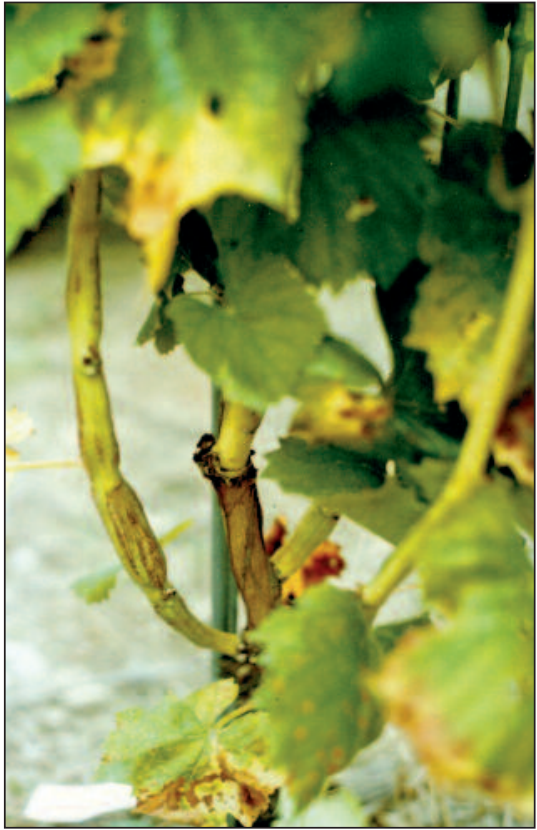

Figure 11. Corky bark (GVB) on the indicator LN33: swelling and grooving on shoot
(GRSPaV), a definitive member of the genus Foveavirus, is the associated agent of Grapevine rupestris stem pitting disease (Monette et al., 1989).

Grapevine virus A (GVA), the type species of the genus Vitivirus, is the putative agent of Grapevine kober stem grooving. Virus particles are flexuous filaments about 800 nm long (Conti et al., 1980).

Grapevine virus B (GVB) is a vitivirus distantly related serologically to GVA and one of the etiological agents associated with Grapevine corky bark. GVB is also involved in young grapevine decline, a graft incompatibility condition recorded from California (Hewitt, 1954).

Geographical distribution: see Table 2. Reported from Hungary first time in 1967 (Martelli et al., 1967, Lehoczky et al., 1968, Lázár et al., 1995).

Transmission: see Table 2. None of the putative agents of rugose wood has alternative hosts in nature and, because of the relatively limited range of vector movement, is not disseminated over long distances by natural means. Transport of infected propagative material represents the major means of dispersal (Frison \& Ikin, 1991).

\section{Fleck complex}

The fleck complex consists of several diseases (grapevine fleck, grapevine asteroid mosaic, grapevine rupestris necrosis, and grapevine rupestris vein feathering) and viruses (Grapevine redglobe virus) that cause latent or semi-latent infections in Vitis vinifera and most American Vitis species and rootstock hybrids (Martelli \& Boudon-Padieu, 2006).

Grapevine fleck was reported from Hungary first time in 1981 (Lehoczky \& Farkas, 1981). Agent: grapevine fleck virus $(\mathrm{GFkV})$, an isometric, phloem-limited, non mecha-

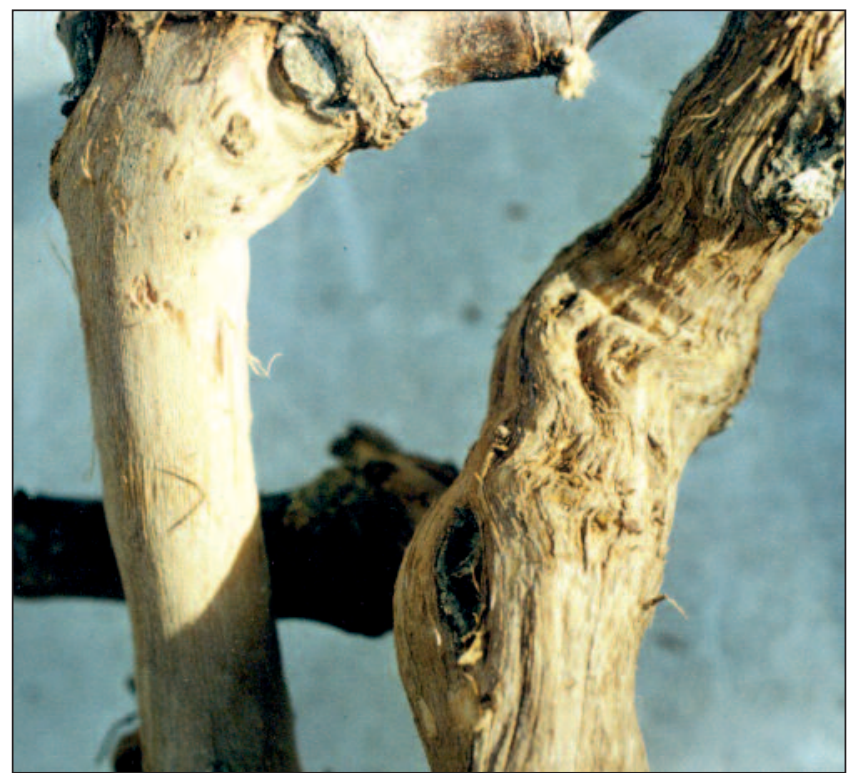

Figure 12. LN stem grooving (LNSG) symptoms on LN 33 (right) and healthy controll (left)

nically transmitted RNA virus, c. $30 \mathrm{~nm}$ in diameter (Boscia et al., 1991; Boulila et al., 1990).

Main symptoms: it is latent in $V$. vinifera and in large number of American rootstocks. Following grafting onto $V$. rupestris St. George indicator, the open field symptoms appear in spring, fleck elicits chlorotic translucents spots along the veins of the third and fourth order. Leaves with intense flecking are wrinkled and twisted and may curl upward (Figure 15) (Garau et al., 1997).

Geographical distribution: see Table 2. (Lázár \& Terjék, 2009; Cseh et al., 2011). 


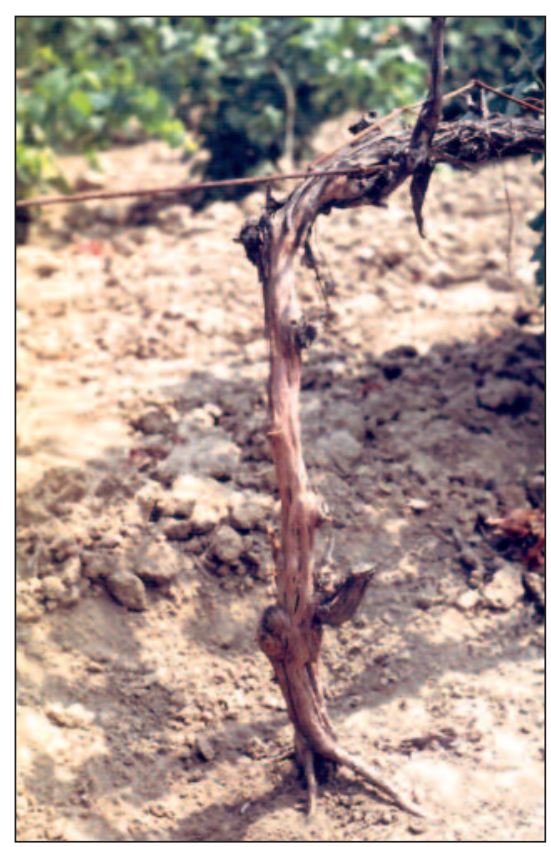

Figure 13. Typical Rugose wood (RW) symptoms on the died ownrooted stok of a susceptible Vitis vinifera variety

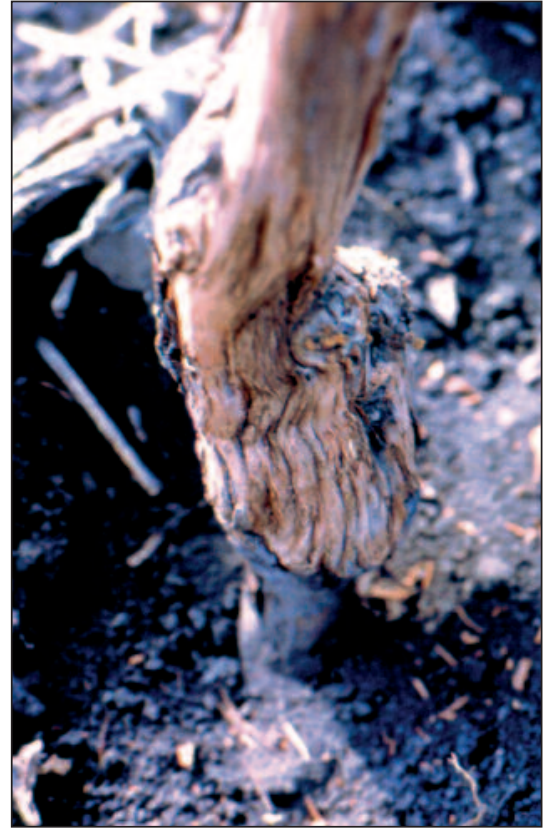

Figure 14. Rugose wood (RW) - corky appearance of the bark above the graft union.

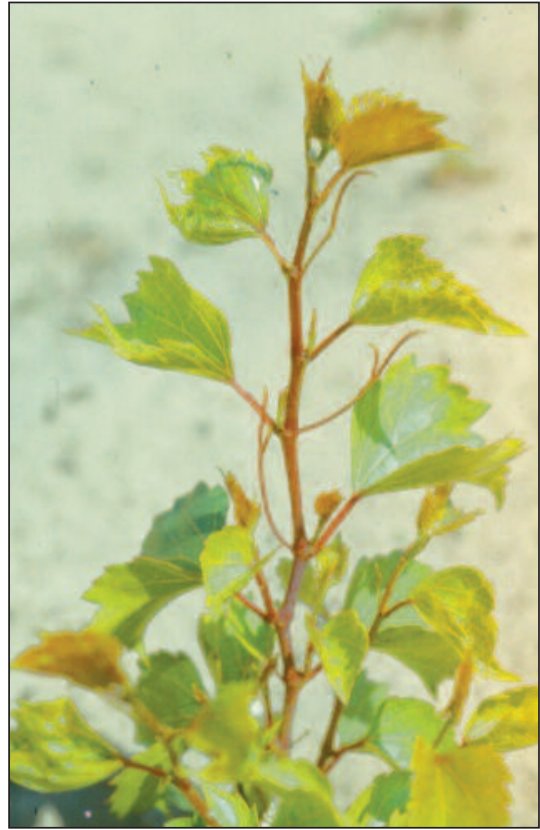

Figure 15. Fleck $(\mathrm{GFkV})$ - clearing of the veinlets and deformation of the leaves.
Transmission: see Table 2. Transmitted by grafting. No vector known. Natural spread reported from South Africa (Engelbrecht \& Kasdorf, 1990).

\section{Minor virus diseases}

Several graft-transmissible diseases are known, with specific viruses are associated and thought to be their possible causal agents. Their overall importance is minor if compared with that of the major diseases dealt with in previous chapters, but some of economic relevance locally. These are Grapevine yellow mottle and Grapevine line pattern in Hungary.

\section{Grapevine yellow mottle}

Main symptoms: The strongest symptoms grow on the lower leaves in spring mostly. Small patches, characteristic yellow rings with a diameter of 3-4 mm, line pattern appear on the infected vines in summer (Figure 16). The symptoms in summer do not mask, merely onto bone-coloured one fade. Plant vigour and yield do not seem appreciably affected.

Agent: Alfalfa mosaic virus (AMV), a mechanically transmissible virus, has differently shaped particles, from quasi isometric to bacilliform, and a tripartite
RNA genome accounting (Martelli \& Boudon-Padieu, 2006).

Geographical distribution: see Table 2. Reported from Hungary first time in 1980 (Lehoczky \& Beczner, 1980; Beczner \& Lehoczky, 1980, 1981).

Transmission: see Table 2. In grapevines infections are scattered and occasional, suggesting that the virus spreads primarily through infected planting material.



Figure 16. Yelow mottle (AMV) - yellow discolorations of the foliage in the form of speckling, blotches, rings and lines

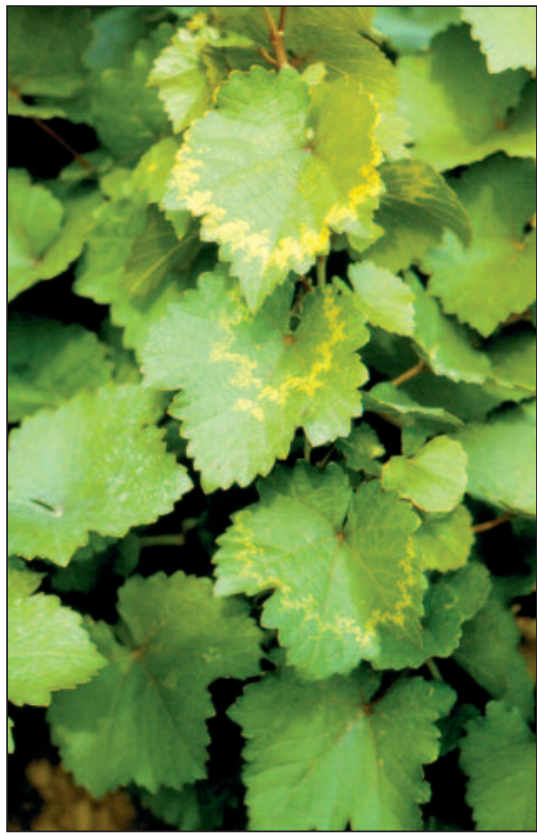

Figure 17. Line pattern (GLPV) - bright yellow discolorations of the leaves in the form of scattered spots of blotches, marginal ring sor maple-leaf line pattern 


\section{Grapevine line pattern}

Main symptoms: Bright yellow discolorations of the leaves in the form of scattered spots of blotches, marginal rings or maple-leaf line pattern (Figure 17). Reduced vigour and yield (Lehoczky et al., 1987).

Agent: Grapevine line pattern virus, a possible member of the Ilarvirus group, with quasi spherical to bacilliform particles, 24 to more than $100 \mathrm{~nm}$ in length and a multipartite RNA genome (Lehoczky et al., 1989).

Geographical distribution: Hungary (GLPV is hungaricum)

Transmission: see Table 2. Transmitted by grafting, through grapevine seeds (Lehoczky et al., 1992) and by mechanical inoculation. GLPV has no known vector.

\section{Virus-like diseases}

Several latent or semi-latent grapevine diseases are known, some of which have a clear-cut detrimental effect on the crop. All persist in propagative material and are transmitted by grafting. Their agent are still unknown, but some are heat-labile and can be eliminated by heat therapy. Known virus-like diseases in Hungary: Enation disease, Vein mosaic, Vein necrosis.

\section{Enation disease}

Main symptoms: Slow and bushy growth of shoots in the initial stages of vegetation. Its symptomatology is characterized by the presence of laminar or cup-shaped outgrowths on the underside of the basal leaves, that develop along the main veins (Figure 18). Symptoms do not recur every year on the same vines.

Agent: unknown, suspected to be a virus.

Geographical distribution: see Table 2. Reported from Hungary by Lehoczky in 1965. (Lehoczky, 1965).

Transmission: see Table 2.

\section{Vein mosaic}

Main symptoms: Pale green discolorations along the main veins, producing a feathering or banding effect (Figure 19). Symptomless infection in European and American Vitis spp. (Legin \& Vuittenez, 1973).

Agent: unknown, suspected to be a virus.

Geographical distribution: see Table 2. Occurrence in hungary reported from 1984 (Lehoczky, et al., 1984).

Transmission: by grafting, no vector known, see Table 2.



Figure 18. Grapevine enation (GEn) - enations on the underside of the leaves of transmitted Vitis vinifera cv. Tramini

\section{Vein necrosis}

Main symptoms: Several European grape cultivars and American rootstocks varieties can be symptomless carriers. The hybrid Vitis rupestris $x$ Vitis berlandieri 110R shows necrosis of veinlets on the underside of the leaf blade and in severe cases, necrosis of the shoot tips (Figure 20) (Legin \& Vuittenez, 1973). Severe reduced growth of the infected indicator shoots can be see in the most cases (Lázár et al., 1992). Frequence of occurrence in Hungary near by $80 \%$ (Lázár et al., 1992, Lázár \& Terjék, 2009).

Agent: unknown, suspected to be a virus.

Geographical distribution: see Table 2. Reported from Hungary first time in 1986 (Lehoczky et al., 1986).

Transmission: by grafting, no vector known, see Table 2 .



Figure 19. Vein mosaic (GVM) - pale green discolorations along the main veins, producing a feathering or banding effect

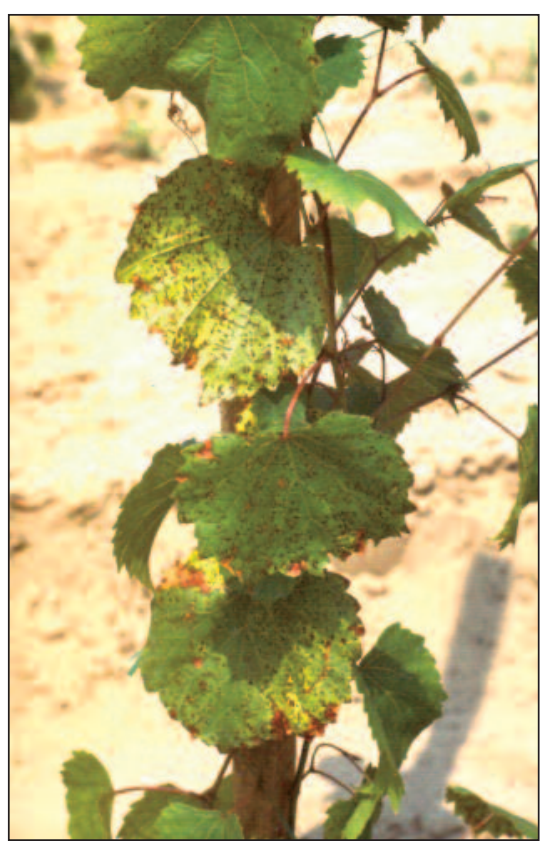

Figure 20. Vein necrosis (GVN) - 110R indicator shows necrosis of the veinlets on the underside of the leaf blade 


\section{Viroids}

Viroids are subviral pathogens consisting of naked circular RNAs (Diener 1971, 1999). Till now Citrus exocortis viroid (CEVd), Hop stunt viroid (HSVd), Grapevine yellow speckle viroid1-2-3 (GYSVd1-2-3) and Australian grapevine viroid (AGVd) are known to naturally infect grapevine (Little \& Rezaian 2003; Tabler \& Tsagris 2004). CEVd and HSVd are distributed worldwide and infect a large number of hosts (Singh et al., 2003). In Hungary research with viroids started with the tomato-Potato spindle tuber viroid (PSTV) host-pathogen interaction (Bisztray et al., 1980; 1981; 1984) where PSTV can cause severe disease symptoms and it is the type species of Pospiviroidae family where all viroids infecting grapevine belong to. On grape plants Farkas and his colleagues made the firs survey and $\mathrm{CEVd}$ and HSVd were detected in mixed infection from vine and rootstock varieties in Hungary (Farkas et al., 1996, 1999). Recently Hop stunt viroid (HSVd) and Grapevine yellow speckle viroid 1 (GYSVd1) were detected in mixed infection (Navarro et al., 2009) using deep sequencing technique. The evaluation of the economical impact of viroids is similar to viruses (Randles 2003). In general, grapevine viroids produce very few, if any, disease symptoms. In mixed infections they can cause severe damage like Grapevine vein-banding disease. It is induced by a synergistic reaction between Grapevine yellow speckle viroid 1(GYSVd1), and Grapevine yellow speckle viroid 2 (GYSVd 2) and Grapevine fenleaf virus (GFLV) (Szychowski et al., 1988; Krake \& Woodham 1983).

\section{Detection of viruses and viroids}

Diseases caused by viroids and viruses can be detected visually upon symptoms, by biological testing using indicator plants (Lázár et al., 2002; Lázár \& Terjék, 2009) and by molecular biology techniques (Gambino et al., 2010). ELISA and RT-PCR techniques are routinely used to detect viruses. These techniques are considered to be sensitive enough to indicate the presence or absence of pathogens however in case of viruses official certification still depends on biological test such as indexing on woody indicators. This situation might change in the future as highly sensitive deep sequencing techniques were introduced. From a symptomatologically negative Hungarian Pinot noir vineyard viruses belonging to the genera of Foveavirus, Maculavirus, Marafivirus and Nepovirus (Pantaleo et al., 2010) and 2 viroids (Hop stunt viroid (HSVd) and Grapevine yellow speckle viroid 1 (GYSVd1)) were detected (Navarro et al., 2009) using deep sequencing technique. This indicates that the pathological statuses of the vineyard are worst than it was expected. Result emphasizes the importance of the sensitivity of the detection methods to evaluate sanitary status of grape plants, the affectivity of techniques to eliminate pathogens, and the use of virus free certified propagating materials.

\section{References}

Alkowni, R., Rowhani, A. \& Golino, D. A. (2002): Partial nucleotide sequence and molecular detection of a putative new grapevine leafroll associated virus. Phytopathology 92 (Supplement to $\left.\mathrm{N}^{\circ} 6\right), \mathrm{S} 3$.

Beczner, L. \& Lehoczky, J. (1980): Szőlőbetegség a lucernamozaik vírus fertőzéstől. II. Vírusátvitel lágyszárú növényekre, szerológia és elektronmikroszkópia. Kertgazdaság, 12: 3. 33-34.

Beczner, L. \& Lehoczky, J. (1981): Grapevine disease in Hungary caused by alfalfa mosaic virus infection. Acta Phytopathol. Acad. Sci. Hung., 16: 119-128.

Bisztray, Gy., Nyitrai, Á., Balogh, J., Andrásfalvy, A. \& Föglein, F.J. (1980): Expression of viroid symptoms under various conditions of host plants having different genetic background. Abstracts of papers. Conference on New Endewours in Plant Protection. Budapest. p. 33.

Bisztray, Gy., Nyitrai, Á., Balogh, J. \& Föglein, F.J. (1981): Viroid symptoms in Lycopersicon esculentum carraying different mutant genes. Abst. of Papers. Fith Int. Cong. of Virology, Strassbourg, France, P21/02.

Bisztray, Gy. (1984): Recovery of tomato plants from viroid induced albinism by chemical treatment. Abst. of papers. Sixth Int. Cong. of Virology, Sendai, Japan. P47.

Boscia, D., Greif, C., Gugerli, P., Martelli, G. P., Walter, B. \& Gonsalves, D. (1995): Nomenclature of grapevine leafrollassociated putative closteroviruses. Vitis, 34: 171-175.

Boscia, D., Martelli, G. P., Savino, V. \& Castellano, M. A. (1991): Identification of the agent of grapevine fleck disease. Vitis, 30: 97-105.

Boulila, M., Boscia, D., Di Terlizzi, B., Castellano, M. A., Minafra, A., Savino, V. \& Martelli, G. P., (1990): Some properties of a phloem-limited non mchanically-transmissible grapevine virus. Journal of Phytopathology. 129: 151-158.

Choueiri, E., Boscia, D., Digiaro, M., Castellano, M. A. \& Martelli, G. P. (1996): Some properties of a hitherto undescribed filamentous virus of the grapevine. Vitis, 35: 91-93.

Conti, M., Milne, R. G., Luisoni, E. \& Boccardo, G. (1980): A closterovirus from a stem pitting-diseased grapevine. Phytopathology, 70: 394:399.

Cseh, E., Daragó, Á., Takács, A. \& Gáborjányi, R. (2011): Szőlővírusok gyakoriságának felmérése magyarországi szőlőültetvényekben. Kertgazdaság, 43. (1): 63-67.

Diener, T. O. (1971): Potato spindle tuber "virus": IV. A replicating, low molecular weight RNA. Virology, 45: 411-428.

Diener, T. O. (1999): Viroids and the nature of viroid diseases. Archives of Virology Supplementum, 15: 203-220.

Engelbrecht, D. J. \& Kasdorf, G. G. F. (1990): Field spread of corky bark, fleck, leafroll and Shiraz decline diseases and associated viruses in South African grapevines. Phytophylactica, 22: 347-354.

Farkas, E., Palkovics, L., \& Balázs, E. (1996): Komló törpülés viroid azonosítása hazai szőlő ültetvényeinkben. 42. Növényvédelmi Tudományos Napok. Budapest, Magyarország, február 27-28.

Farkas, E., Palkovics, L., Mikulás, J. \& Balázs, E. (1999): High incidence of hop stunt viroid in hungarian Grapevines. Acta Phytopathologica et Entomologica Hungarica. 34. 1/2. 7-11. p. b: 11. p.

Ferreira, A. A. \& Sequeira, A. O. De (1972): Preliminary studies on an undescribed grapevine virus. Ann. Phytopathol. No hors série: 113-120. 
Frison, E.A. \& Ikin, R. (eds.). (1991): FAO/IBPGR Technical Guidelines for the Safe Movement of Grapevine Germplasm. Food and Agriculture Organization of the United Nations, Rome/ Internatzional Board for Plant Genetic Resources, Rome

Fuchs, M., Pinck, M. Etienne, L., Pinck, L. \& Walter, B. (1991): Characterization and detection of grapevine fanleaf virus using cDNA probes. Phytopathology, 81: 559-565.

Gambino, G., Angelini, E. \& Gribaudo, I. (2010): Field Assessment and Diagnostic Methods for Detection of Grapevine Viruses. pp.: 211-228 in: Delrot, S. Medrano,H. Or, E., Bavaresco, L. \& Grando, S. (Eds.) Methodologies and Results in Grapevine Research. Springer Dordrecht Heidelberg London New York

Garau, R., Padilla, V., Rumbos, I., Walter, B. \& Savino, V. (1997): Indexing for the identification of virus and virus-like diseases of the grapevine. Sanitary selection of the grapevine. Colmar (France), October 9, 1997. Ed. INRA, Paris 1997 (Les Colloques, $\mathrm{N}^{\circ}$ 86) 97-117.

Garau, R., Prota, V. A. \& Cugusi, M. (1989): Investigations on wood disorders (stem pitting and/or stem grooving) of grapevine in Sardinia. Proc. 9th Meeting ICVG, Kiryat Anavim, 1987, 135-141.

Goheen, A. C. (1988): Rupestris stem pitting. In Pearson R. C. \& A. C. Goheen (Eds.): Compendium of Grape Diseases. Americ. Phytopath. Soc. Press, St. Paul, Minnesota, USA, 53.

Gugerli, P., Brugger, J. J. \& Bovey, R. (1984): L'enroulement de la vigne: mise en evidence de particules virales et développement d'une méthode immuno-enzimatique pour le diagnostic rapide. Revue Suisse de Viticulture Arboriculture et Horticulture, 16: 299-304.

Hévin M., Ottenwaelter, M. M., Doazan, J. P. \& Rives, M. (1973): Investigating the transmission of marbrure and fan-leaf through the seed int he grapevine. Rivista di Patologia Vegetale, Ser. IV, 9: 253-258

Hewitt, W. B. (1954): Some virus and virus-like diseases of grapevine. Bulletin of the California Department of Agriculture 43: 47-64.

Hewitt, W. B., Gohen, A. C., Raski, D. J. \& Gooding, G. V. Jr., (1962): Studies on virus diseases of the grapevine in California. Vitis, 3: 57-83.

Hewitt, W. B. (1954): Some virus and virus-like diseases of grapevines. Calif. Dept. Agric. Bull., 43: 47-64.

Hewitt, W. B. (1976): On the origin and ditribution of virus and virus-like diseases of the grapevine. Proc. 6th Meet. ICVG Cordoba, Monografias INIA, 1979, 18: 3-5.

Horváth, J., Tobiás, I. \& Hunyadi, K. (1994): New natural herbaceous hosts of grapevine fanleaf nepovirus. Horticultural Science 26: 31-32.

Hu, J. S., Gonsalves, D. \& Teliz, D. (1990): Characterization of closterovirus-like particles associated with grapevine leafroll disease. Journal of Phytopathology, 128: 1-14.

Izadpanah, K., Zaki-Aghl, M. \& Rowhani, A. (2003): Non-vitis hosts of Grapevine fanleaf virus and their possible epidemiological significance. Extended abstracts of the 14th meeting of ICVG, Locorotondo, 210.

Jenser, G., Schuster, V., Seljahudin, A. \& Mahunka, M. (1979): Az Arabis mozaikvírus fennmaradását meghatározó vektor-gyomnövény kapcsolat vizsgálata. Kertgazdaság, 11 (3): 15-20.

Kobza, S. \& Lázár, J. (1994): Mitől sárgul a szőlő? (2.) Vírusbetegségek. Agrofórum, 5. (8): 13-15.

Krake, R. L. \& Woodham, R. C. (1983): Grapevine yellow speckle agent implicated in the aetiology of vein banding disease. Vitis, 22: 40-50.

Lázár, J. (2003): Sanitary aspects and results of the Hungarian grape breeding. proceedings of the VIIIth International Conference on Grape Genetics and Breeding, Acta Horticulturae 603, ISHS $755-762$.

Lázár, J. \& Terjék, M. (2009): Frequence of occurrence of grapevine virus disease-complexes based on over 30-year indexing results in Hungary. Extended abstracts of the 16th meeting of ICVG, Dijon, France, 124-125.

Lázár, J., Farkas, G. \& Lehoczky, J. (1992): A szőlő látens vírusbetegségeinek hazai elterjedése és kórfolyamatainak hatása egyes európai- és alanyfajták növekedésére. 38. Növényvédelmi Tudományos Napok. Budapest, 25-26: 94. p.

Lázár, J., Farkas, Gné, \& Mikulás, J. (2002): A tesztelt szőlőtőkék komplex vírusbetegsége. Növényvédelmi Tudományos Napok, Budapest, 2002. március 6-7. p. 85.

Lázár, J., Farkas, Gné, Ország, M. \& Mikulás, J. (2003): Vírusbetegségek komplex fertőzésének hatása alanyszőlő fajták hajtásnövekedésére 49. Növényvédelmi Tudományos Napok, Budapest, 164.

Lázár, J., Farkas, Gné., Farkas, E. \& Mikulás, J. (1995a): A Rugose wood komplex egyes tagjainak azonosítása Magyarországon, fás indikátorok használatával. 41. Növényvédelmi Tudományos Napok. Budapest, 1995. febr. 21-22. 95.

Lázár, J., Kölber, M., Farkas, E., Farkas, G. \& Lehoczky, J. (1995b): Occurrence of grapevine leafroll associated closteroviruses (GLRaV-s) in Hungary. Abstracts of 47th International Symposium on Crop protection, Gent, Belgium, 9 May, 1995. 307-308.

Lázár, J., Kölber, M. \& Lehoczky, J. (1990): Detection of some nepoviruses (GFLV, GFLV-YM, GCMV, ArMV) in the seeds and seedlings of grapevines by ELISA. Kertgazdaság, 22 (4): 58-72.

Lázár, J., Mikulás, J., Farkas, G. \& Kölber, M. (2002): Certification programme for production of virus-free propagating material of grapevine and its results in Hungary. Intern. Journ. of Hortic. Sci., 8, (3-4): 39-43.

Lázár, J., Mikulás, J., Hajdu, E., Kölber, M. \& Szőnyegi, S. (2000): Grapevine virus diseases and clean grape stock program in Hungary. Extended abstracts 13th meeting of ICVG, Adelaide, Australia, 172-173.

Legin, R. \& Vuittenez, A. (1973): Comparaison des symptomes et transmission par greffage d'une mosaique nervaire de Vitis vinifera, de la marbrure de $V$. rupestris et d'une affection nécrotique des nervures de l'hybride Rup.-Berl. 110 R. Rivista di Patologia Vegetale, Ser. IV, 9: 57-63.

Lehoczky, J. (1965): Research on virus diseases of grapevines in Hungary. Proceedings of International Conference on Virus and Vector On Perennial Hosts, with Special Reference to Vitis. Paris, Sept 6-10, 1965. University of California. Division of Agricultural Sciences California, USA. 311-318.

Lehoczky, J. (1985): Detection of grapevine chrome mosaic virus in naturally infected vines by indexing. Phytopathologia Mediterranea 24: 129-134.

Lehoczky, J. \& Beczner, L. (1980): Szőlőbetegség a lucernamozaik vírus fertőzéstől. Kertgazdaság, 18: 2. 58-66.

Lehoczky, J., Boscia, D., Burgyán, J., Castellano, M. A., Beczner, L. \& Farkas, G. (1989): Line pattern, a novel virus disease of grapevine in Hungary. Procedings 9th meeting of ICVG, Kiryat Anavim, Israel, 23-30.

Lehoczky, J., Boscia, D., Martelli, G. P., Burgyán, J., Castellano, M. A., Beczner, L. \& Farkas, G. (1987): Occurrence of the line pattern hitherto unknown virus disease of grapevine in Hungary. Kertgazdaság 19: 61-79. 
Lehoczky, J. \& Burgyán, J. (1986): A paradicsom fekete gyürüs vírus előfordulása szőlőben Magyarországon. Kertgazdaság, 18. (4): 47-57.

Lehoczky, J. \& Farkas, G. (1981): A szőlő látens foltosságának előfordulása Magyarországon. Kertgazdaság, 18. (1): 15-26.

Lehoczky, J., Farkas, G. \& Lázár, J. (1984): Új szőlőfajták és klónok vírustesztelése és mentesítési módszerek kidolgozása. Az érmenti mozaik hazai előfordulásának igazolása. KÉE SZBKI, Kecskemét, Évi kutatási jelentés

Lehoczky, J., Farkas, G. \& Lázár, J. (1986): Detection of vein necrosis virus (GVNV) in the vines of cultivated grape varieties. Kertgazdaság 18. (4): 59-65.

Lehoczky, J., Luntz, O., Lázár, J., Kölber, M., Mikulás, J. \& Farkas, G. (1992): Production of virus free grapevine propagating material in Hungary. $44^{\text {th }}$ Internat. Symp. Crop Protection. Gent, Belgium. 333-339.

Lehoczky, J., Martelli, G. P. \& Lázár, J. (1992): Seed transmission of grapevine line pattern virus. Phytopathologia Mediterranea 31: 115-116.

Lehoczky, J., Martelli, G. P. \& Sárospataki, Gy. (1969): Leafroll of grapevine in Hungary. Acta Phytopathology Acad. Sci. Hung. 4. (2-3): 117-124.

Lehoczky, J., Martelli, G. P., Sárospataki, Gy. \& Quacquarelli, A. (1968): Újabb megfigyelések a faszöveti barázdáltság /legno riccio, Rugose wood/ előfordulásáról Magyarországon, sajátgyökerű szőlőtőkéken. Orsz. Szől. Bor. Kut. Int. Évkönyve, 13: 127-134.

Lehoczky, J., Sárospataki, Gy., Devergne, J. C., Cardin, L., Kuszala, J. \& Vuittenez, A. (1979): Caractérization d'une souche du virus de la mosaique jaune crome de la vigne (GCMV) isolée en Hongrie de vignes non panachées. Nouvelle évidence d'une parenré sérologique éloignée entre ce virus et celui deas anneaux noirs de la tomate (TBRV). Annales de Phytopathologie 11: 567-568.

Little, A., \& Rezaian, M.A. (2003): Grapevine viroids. In: Hadidi A, Flores R, Randles JW, Semancik JS, eds. Viroids. Australia: CSIRO Publishing, 195-206.

Martelli, G. P., Agranovsky, A. A., Bar-Joseph, M., Boscia, D., Candresse, T., Coutts, R. H. A., Dolja, V. V., Falk, B. W., Gonsalves, D., Jelkmann, W., Karasev, A. V., Minafra, A., Namba, S., Vetten, H. J., Wisler, G. C. \& Yioshikawa, N. (2002): The family Closteroviridae revised. Archives of Virology 147: 2039-2043.

Martelli, G. P. \& Boudon-Padieu, E. (2006): Directory of infectious diseases of grapevines and viroses and virus-like diseaes of the grapevine, Bibliographic report 1998-2004. Options Méditerranéennes, Serie B: Studies and Research 55: 279.

Martelli, G. P. \& Lehoczky, J. (1968): Isolation of arabis mosaic virus from Hungarian grapevines. Phytopath. Med. 7. (2-3): 129-133.

Martelli, G. P., \& Piro, G. (1975): Virus diseases of the grapevine in a Sicilian herbarium of the past century. Vitis, 13: 329-335.

Martelli, G. P., Lehoczky, J. \& Quacquarelli, A. (1965): Host range and properties of a virus associated with Hungarian grapevines showing macroscopic symptoms of fanleaf and yellow mosaic. Proc. of Int. Conf. on Virus and Vector on Perennial Hosts, with special Reference to Vitis. Davis. Californa. Sept. 6-10. 1965. Publ. Univ. Calif. Div. Agr. Sci. Dept. of Plant Pathology. 389-401. Martelli, G.P., Quacquarelli, A., Lehoczky, J. \& Sárospataki, Gy. (1967): A disorder resembling „legno riccio” (Rugose wood) of grapevine in Hungary. Phytopath. medit. 6. (1-2): 110-112.
Monette, P. I., James, D. \& Godkin, S. E. (1989): Double-stranded RNA from rupestris stem pitting-affected grapevines. Vitis, (28): 137-144.

Monis, J. (2000): Development of monoclonal antibodies reactive to a new grapevine leafroll-associated closterovirus. Plant Disease 84: 858-862.

Navarro, B., Pantaleo, V., Gisel, A., Moxon, S., Dalmay, T., Bisztray, Gy. D., Di Serio, F. \& Burgyán, J. (2009): Deep Sequencing of Viroid-Derived Small RNAs from Grapevine Provides New Insights on the Role of RNA Silencing in PlantViroid Interaction. PLoS ONE 4: 7686.

Quacquarelli, A., Gallitelli, D., Savino, V. \& Martelli, G. P. (1976): Properties of grapevine fanleaf virus. Journal gen. Virol. 32: 349-360.

Panjan, M. \& Saric, A. (1963): Serological detection of arabis mosaic virus in grapevine and sweet chery by gel diffusion technigue. Agronomski glasnik, 13: 204-206.

Pantaleo, V., Saldarelli, P., Miozzi. L., Giampetruzzi, A., Gisel, A., Moxon, S., Dalmay, T., Bisztray, G. \& Burgyan, J. (2010): Deep sequencing analysis of viral short RNAs from an infected Pinot Noir grapevine. Virology. 408 (1): 49-56.

Pocsai, E. (1981): Occurrence of grapevine Bulgarian latent virus in Hungary. Acta Phytopathologica Academiae Scientiarum Hungaricae 16: 349-354.

Randles, J. W. (2003): Economic impact of viroid diseases. pp.: 3-11 in: Hadidi, A., Flores, R., Randles, J. W. \& Semancik, J. S. Viroids. CSIRO Publishing, Australia

Ravaz, L. \& Verge, G. (1924): Le rugeau de la vigne. Progrés Agricole et Viticole 45: 11-17, 35-38, 86-89, 110-113, 135-141.

Rosciglione, B. \& Gugerli, P. (1986): Maladies de l'enroulement et du bois strié de la vigne: analyse microscopique et sérologique. Revue Suisse de Viticulture Arboriculture et Horticulture 18: 207-211.

Sárospataki, Gy. (1964): A szőlő vírusbetegségek hazai vizsgálata. Kisérl. Közl. 57/C, 63-80.

Sárospataki, Gy. (1965): Untersuchungen von Viruskrankheiten der Reben in Ungarn. Wein Wiss. 20-37.

Sannino, F. A. (1906): Il rossore delle viti. Rivista di Patologia Vegetale 1: 162-163.

Savino, V., Boscia, D. \& Martelli, G. P. (1987): Rugose vood complex of grapevine: can grafting to Vitis indicators discriminate between diseases? Proc. 9th Meeting ICVG, Kiryat Anavim, 91-94. Singh, R. P., Ready, K. F. M. \& Nie, X. (2003): Biology. pp.: 30-48 in: Hadidi, A., Flores, R., Randles, J. W. \& Semancik, J. S. Viroids. CSIRO Publishing, Australia

Stellmach, G. \& Bercks, R. (1963): Untersuchungen an Rebenvirosen: Nachweis des Tomatenschwarzringflecken-Virus (tomato blackring virus) in kranken Reben der Sorte Aramon X Riparia 143 A.M.G. (Amerikanerrebe). Phytopath. Zeit., 53: 383-390.

Szychowski, J. A., Goheen A. C. \& Semancik, J. S. (1988): Mechanical Transmission and Rootstock Reservoirs as Factors in the Widespread Distribution of Viroids in Grapevines. American Journal of Enology and Viticulture, 39: 213-216.

Tabler, M. \& Tsagris, M. (2004): Viroids: petite RNA pathogens with distinguished talents. Trends in Plant Science, 9: 339-348.

Walter, B. \& Zimmermann, D. (1991): Further characterization of closterovirus-like particles associated with the grapevine leafroll disease. Proceedings 10th Meeting of ICVG, Volos 1990, 62-66. 